\title{
Halobacillus gen. nov., with Descriptions of Halobacillus litoralis sp. nov. and Halobacillus trueperi sp. nov., and Transfer of Sporosarcina halophila to Halobacillus halophilus comb. nov.
}

\author{
S. SPRING, ${ }^{1 *}$ W. LUDWIG, ${ }^{1}$ M. C. MARQUEZ, ${ }^{2}$ A. VENTOSA, ${ }^{2}$ AND K.-H. SCHLEIFER ${ }^{1}$ \\ Lehrstuhl für Mikrobiologie, Technische Universität München, D-80290 Munich, Germany, ${ }^{1}$ and Department of \\ Microbiology and Parasitology, Faculty of Pharmacy, University of Seville, Seville, Spain ${ }^{2}$
}

\begin{abstract}
Two moderately halophilic, gram-positive, heterotrophic bacterial strains were isolated from hypersaline sediments of the Great Salt Lake in Utah. These two strains, designated SL-4 ${ }^{\mathrm{T}}\left(\mathrm{T}=\right.$ type strain) and SL-5 ${ }^{\mathrm{T}}$, were motile, spore-forming, strictly aerobic rods which contained peptidoglycan of the Orn-D-Asp type in their vegetative cell walls. The guanine-plus-cytosine contents of the DNAs of strains SL-4 ${ }^{T}$ and SL-5 ${ }^{T}$ were 42 and $43 \mathrm{~mol} \%$, respectively. A detailed investigation of the phenotypic and phylogenetic characteristics of these organisms revealed that each isolate represents a new species that is closely related to Sporosarcina halophila, a moderately halophilic, spore-forming coccus. Phylogenetic data indicate that there is only a distant relationship between Sporosarcina halophila and Sporosarcina ureae, the type species of the genus Sporosarcina. The sequences of the 16S rRNA genes of strain SL-4 ${ }^{T}$ and Salinicoccus roseus DSM 5351 were determined. We propose that a new genus, Halobacillus, should be created; this genus includes Halobacillus halophilus (formerly Sporosarcina halophila) as the type species, as well as Halobacillus litoralis DSM $10405^{\mathrm{T}}\left(=\mathrm{SL}^{\mathrm{T}}\right)$ and Halobacillus trueperi DSM $10404^{\mathrm{T}}\left(=\mathrm{SL}-5^{\mathrm{T}}\right)$.
\end{abstract}

The Great Salt Lake is a hypersaline lake that is located in Utah and is divided by a railroad causeway into two parts. The two parts differ significantly in their levels of salinity. Since freshwater can enter only from the south, the level of salinity in the north arm has increased to up to $33 \%$ (wt/vol) because of evaporation (18). Cultivation studies have revealed that extremely halophilic archaea are the predominant members of the microbial population in the north arm, whereas moderately halophilic bacteria dominate in the south arm (7). Workers have performed several studies to investigate the microbial diversity of the north arm, but there is little information available about the aerobic, moderately halophilic population in the south arm. In general, moderately halophilic microorganisms grow optimally in media containing 3 to $15 \%$ (wt/vol) salt (10), and these organisms are distributed among diverse taxonomic groups in the domains Bacteria and Archaea (26). There have been many descriptions of gram-negative, moderately halophilic species belonging to the domain Bacteria, whereas there have been only a few reports about gram-positive, moderately halophilic bacteria $(3,8,17,27,28)$. In this paper we extend the range of observed phenotypes of aerobic, heterotrophic bacteria found in hypersaline sediments by describing two moderately halophilic, gram-positive, rod-shaped bacterial species.

\section{MATERIALS AND METHODS}

Sampling site and isolation procedure. A sample of surface sediment was obtained from the south arm of the Great Salt Lake in Utah near Salt Lake City and was transported within 1 week to a laboratory in a 1-liter plastic bottle. The salinity of the sample was determined to be $18.5 \%$ with a refractometer. Aliquots of the sediment were suspended in water containing $20 \%$ (wt/vol) $\mathrm{NaCl}$. After the sediment had settled, $0.1-\mathrm{ml}$ portions of supernatant were spread onto isolation medium containing (per liter) $200 \mathrm{~g}$ of $\mathrm{NaCl}, 20 \mathrm{~g}$ of $\mathrm{MgSO}_{4} \cdot 7 \mathrm{H}_{2} \mathrm{O}, 0.1$ $\mathrm{g}$ of $\mathrm{MnCl}_{2} \cdot 4 \mathrm{H}_{2} \mathrm{O}, 0.1 \mathrm{~g}$ of $\mathrm{KCl}, 5 \mathrm{~g}$ of casein peptone, $3 \mathrm{~g}$ of yeast extract, and $15 \mathrm{~g}$ of agar. The $\mathrm{pH}$ was adjusted to 7.2 .

After incubation at $30^{\circ} \mathrm{C}$ for several days, white- and orange-pigmented colonies began to appear on the agar plates. No colonies with the red pigmentation typical of halophilic archaea were observed. Orange colonies formed by rod-

\footnotetext{
* Corresponding author.
}

shaped bacteria were picked and restreaked several times to obtain pure cultures. Two strains were chosen for detailed characterization.

Bacterial strains and growth media. The newly isolated strains have been deposited in the Deutsche Sammlung von Mikroorganismen as Halobacillus litoralis DSM $10405^{\mathrm{T}}\left(=\mathrm{SL}-4^{\mathrm{T}}\right)(\mathrm{T}=$ type strain) and Halobacillus trueperi DSM $10404^{\mathrm{T}}\left(=\mathrm{SL}-5^{\mathrm{T}}\right)$. The medium used for maintenance and growth of these strains contained (per liter) $100 \mathrm{~g}$ of NaCl, $5 \mathrm{~g}$ of $\mathrm{MgSO}_{4} \cdot 7 \mathrm{H}_{2} \mathrm{O}, 5 \mathrm{~g}$ of casein peptone, and $3 \mathrm{~g}$ of yeast extract. The $\mathrm{pH}$ of this medium was adjusted to 7.5. Solid media were prepared by adding $15 \mathrm{~g}$ of agar per liter. Seawater agar was used to observe spore-forming cells (6). This medium contained (per liter) $50 \mathrm{~g}$ of $\mathrm{NaCl}, 10.99 \mathrm{~g}$ of $\mathrm{MgCl}_{2} \cdot 6 \mathrm{H}_{2} \mathrm{O}, 4.06 \mathrm{~g}$ of $\mathrm{Na}_{2} \mathrm{SO}_{4}, 1.51 \mathrm{~g}$ of $\mathrm{CaCl}_{2} \cdot 2 \mathrm{H}_{2} \mathrm{O}, 0.69$ $\mathrm{g}$ of $\mathrm{KCl}, 0.20 \mathrm{~g}$ of $\mathrm{NaHCO}_{3}, 0.10 \mathrm{~g}$ of $\mathrm{KBr}, 0.1 \mathrm{~g}$ of $\mathrm{FePO}_{4} \cdot 4 \mathrm{H}_{2} \mathrm{O}, 0.042 \mathrm{~g}$ of $\mathrm{SrCl}_{2} \cdot 6 \mathrm{H}_{2} \mathrm{O}, 0.027 \mathrm{~g}$ of $\mathrm{H}_{3} \mathrm{BO}_{3}, 0.01 \mathrm{~g}$ of $\mathrm{MnCl}_{2} \cdot 4 \mathrm{H}_{2} \mathrm{O}, 0.005 \mathrm{~g}$ of $\mathrm{Na}_{2} \mathrm{Si}_{3} \mathrm{O}_{7} \cdot \mathrm{H}_{2} \mathrm{O}, 0.003 \mathrm{~g}$ of NaF, $0.002 \mathrm{~g}$ of $\mathrm{NH}_{4} \mathrm{NO}_{3}, 5.0 \mathrm{~g}$ of casein peptone, 1.0 $\mathrm{g}$ of yeast extract, and $15.0 \mathrm{~g}$ of agar; the $\mathrm{pH}$ was adjusted to 7.5 .

Salinicoccus roseus DSM $5351^{\mathrm{T}}$ and Sporosarcina halophila DSM $2266^{\mathrm{T}}$ were used for comparison; these strains were obtained from the Deutsche Sammlung von Mikroorganismen und Zellkulturen GmbH, Braunschweig, Germany. The recommended growth media were used to grow these organisms.

Phenotypic characterization. The cellular morphology of the newly isolated bacteria was studied by using phase-contrast microscopy (Axioplan; Zeiss, Oberkochen, Germany). To obtain photomicrographs of sporulating bacteria, slides were thinly coated with water agar $(2 \%, \mathrm{wt} / \mathrm{vol})$. Flagellation was studied by using the staining methods described by Drews (5) or Heimbrook et al. (9).

Whether the isolates grew in the presence of different salt concentrations was determined by using complex medium containing 0.5 to $30 \%$ (wt/vol) marine salts (29). All other growth characteristics were determined by using the maintenance medium. The temperature range for growth was determined by incubating agar plates at temperatures between 5 and $45^{\circ} \mathrm{C}$. The $\mathrm{pH}$ range for growth was determined by adjusting the final $\mathrm{pH}$ of the medium to values between 5.5 and 10.0 with $\mathrm{NaOH}$ or $\mathrm{HCl}$. Growth rates were determined by measuring the turbidity of cultures at $660 \mathrm{~nm}$. with a UV/Vis spectrophotometer (Pharmacia LKB, Freiburg, Germany).

Physiological and biochemical tests were performed as described previously $(19,29)$.

Peptidoglycan analysis. The interpeptide bridge in the cell wall peptidoglycans was analyzed by using the methods described by Schleifer and Kandler (22). Total hydrolysates of cell walls were separated by one-dimensional or twodimensional chromatography on cellulose thin layers (Merck, Darmstadt, Germany). The following amino acids were used as references in the thin-layer chromatography experiments: L-ornithine, L-lysine, and meso-diaminopimelic acid.

DNA base compositions and levels of DNA-DNA similarity. Chromosomal DNA was isolated and purified by the method of Meyer and Schleifer (15). The $\mathrm{G}+\mathrm{C}$ content of DNA was determined from the midpoint of the thermal denaturation profile obtained with a Gilford model 2600 spectrophotometer (13). The $\mathrm{G}+\mathrm{C}$ content was calculated by using the equation of De Ley (4) and Escherichia coli ATCC $11775 \mathrm{DNA}$ as the reference ( $\mathrm{G}+\mathrm{C}$ content, $51 \mathrm{~mol} \%$ ).

DNA-DNA hybridization experiments were performed by using a modification 


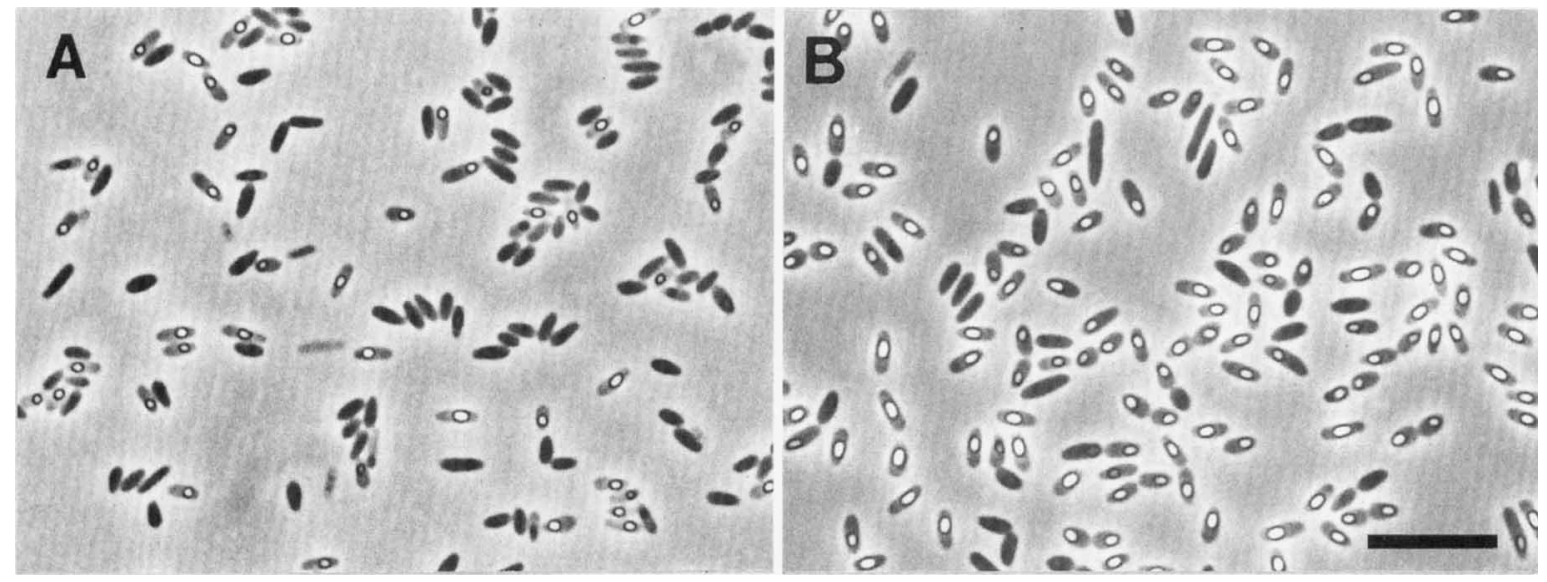

FIG. 1. Phase-contrast micrographs of strains SL-4 ${ }^{\mathrm{T}}$ (A) and SL-5 ${ }^{\mathrm{T}}$ (B) showing spore-forming cells. Bar $=10 \mu \mathrm{m}$.

of the hydroxyapatite method of Lind and Ursing (11). DNAs were labelled with $\left[\alpha{ }^{32} \mathrm{P}\right] \mathrm{dCTP}$ by using the nick translation method (Boehringer, Mannheim, Germany) described by Rossello-Mora et al. (20). The radioactively labelled DNA was reacted with unlabelled DNA under optimal conditions for $16 \mathrm{~h}$. An incubation temperature that was $25^{\circ} \mathrm{C}$ below the thermal denaturation midpoint of the radioactively labelled DNA was considered optimal, as described by Marmur and Doty (14). The pooled standard deviation for the experiment was $1.8 \%$.

Phylogenetic analysis. In vitro amplification of $16 \mathrm{~S}$ rRNA genes and direct sequencing of the amplified DNA fragments were performed as previously described (24). The newly determined sequences were added to an alignment of more than 2,000 bacterial 16S rRNA sequences available from rRNA sequence databases $(12,25)$. Data analyses were performed with the ARB software package as described previously $(20,23)$. Distance matrix trees were reconstructed by using the neighbor-joining method of Saitou and Nei (21). The trees inferred were compared with the results of a parsimony analysis of the complete data set.

Nucleotide sequence accession numbers. The newly determined sequences of the 16S rRNA genes of Halobacillus litoralis and Salinicoccus roseus have been deposited in the EMBL data library under accession numbers X94558 and X94559, respectively.

\section{RESULTS}

Cellular and colonial morphology. The cells of newly isolated strains $\mathrm{SL}-4^{\mathrm{T}}$ and $\mathrm{SL}-5^{\mathrm{T}}$ were similar in morphology. They were gram-positive rods with pointed ends that occurred singly, in pairs, or in short chains. Under optimal conditions the cells of strain SL-4 ${ }^{\mathrm{T}}$ were 0.7 to 1.1 by 2.0 to $4.5 \mu \mathrm{m}$, and the cells of strain SL- $5^{\mathrm{T}}$ were somewhat wider $(0.7$ to 1.4 by 2.0 to $4.5 \mu \mathrm{m}$ ). The cells of both strains were motile by means of flagella, which occurred predominantly as tufts at both poles of each cell. Lateral flagella were also observed sometimes. Under conditions that were not optimal for growth the majority of the cells were nonmotile and elongated cells up to $20 \mu \mathrm{m}$ long occurred. Both strains formed endospores after growth on seawater agar. The spores were ellipsoidal or sometimes spherical (diameter, 0.7 to $1.5 \mu \mathrm{m}$ ) and were located at a central to subterminal position. The spores survived heating at $75^{\circ} \mathrm{C}$ for at least $10 \mathrm{~min}$. The frequency of spore-forming cells was higher among strain SL- $5^{\mathrm{T}}$ cells than among strain SL-4 ${ }^{\mathrm{T}}$ cells (Fig. 1).

Colonies of both strains were 1 to $2 \mathrm{~mm}$ in diameter, circular, smooth, slightly raised, and orange pigmented. The pigment was insoluble in water and nondiffusible. The pigmentation varied with the salt concentration of the medium.

Growth and metabolic properties. Strain SL- $4^{\mathrm{T}}$ grew in media containing 0.5 to $25 \%$ (wt/vol) salt, and optimum growth occurred in medium containing around $10 \%$ salt. This strain grew at temperatures ranging from 10 to $43^{\circ} \mathrm{C}$, and the opti- mum temperature for growth was $35^{\circ} \mathrm{C}$. The $\mathrm{pH}$ range for growth was $\mathrm{pH} 6.0$ to 9.5 , and the optimum $\mathrm{pH}$ was 7.5.

Strain SL- $5^{\mathrm{T}}$ grew in media containing 0.5 to $30 \%$ (wt/vol) salt, and optimum growth occurred in medium containing around $10 \%$ salt. The temperature range for growth of this organism was 10 to $44^{\circ} \mathrm{C}$, and the optimum temperature was $35^{\circ} \mathrm{C}$. The optimum $\mathrm{pH}$ for growth was 7.7 ; no growth occurred at $\mathrm{pH}$ values below 6.0 or above 9.5 .

Under optimal conditions both strains grew relatively fast; the doubling times were $0.48 \mathrm{~h}$ for SL $-4^{\mathrm{T}}$ and $0.42 \mathrm{~h}$ for SL $-5^{\mathrm{T}}$. Strains SL-4 ${ }^{\mathrm{T}}$ and SL-5 $5^{\mathrm{T}}$ grew only under aerobic conditions and produced catalase and oxidase. Broth cultures of both strains were uniformly turbid. Biochemical and physiological characteristics useful for identifying and differentiating strains SL- $4^{\mathrm{T}}$ and SL- $5^{\mathrm{T}}$ and the type strain of Sporosarcina halophila are shown in Table 1.

Peptidoglycan types. The peptidoglycan composition of the cell walls of strains SL- ${ }^{\mathrm{T}}$ and SL-5 ${ }^{\mathrm{T}}$ was similar to that of Sporosarcina halophila. The peptidoglycan type was Orn-DAsp.

DNA base composition and levels of DNA-DNA similarity. The $\mathrm{G}+\mathrm{C}$ contents of the DNAs of strains SL- $4^{\mathrm{T}}$ and SL-5 were 42 and 43 mol\%, respectively. DNA-DNA hybridization experiments revealed low levels of similarity (18 to 24\%) between Sporosarcina halophila DSM $2266^{\mathrm{T}}$ DNA and strain SL $-4^{\mathrm{T}}$ and SL $-5^{\mathrm{T}}$ DNAs. The highest level of similarity found $(30 \%)$ was the level of similarity between labelled strain SL $-4^{\mathrm{T}}$ DNA and unlabelled strain SL- $5^{\mathrm{T}}$ DNA.

Phylogeny. The almost complete 16S rRNA sequence of strain SL- $4^{\text {T }}$ was determined. Partial sequencing of the $16 \mathrm{~S}$ rRNA gene of strain SL- $5^{\mathrm{T}}$ showed that the sequence of this gene was indistinguishable from the SL- $4^{\mathrm{T}}$ sequence in a variable part near the $5^{\prime}$ end of the $16 \mathrm{~S}$ rRNA (positions 100 to $450 ; E$. coli $16 \mathrm{~S}$ rRNA numbering). In addition, the sequence of the 16S rRNA gene of Salinicoccus roseus was determined because the genus Salinococcus is another genus of grampositive halophilic bacteria. Table 2 shows the results of a comparison of the $16 \mathrm{~S}$ rRNA sequence of strain SL- $4^{\mathrm{T}}$ and the 16S rRNA sequences of other gram-positive bacteria. The highest level of similarity found $(97.9 \%)$ was the level of similarity between the sequences of SL- ${ }^{\mathrm{T}}$ and Sporosarcina halophila, whereas the level of similarity between the strain SL-4 ${ }^{\mathrm{T}}$ sequence and the 16S rRNA sequence of Sporosarcina ureae was only $91.0 \%$. Among the Bacillus species, Bacillus pantothenticus, which belongs to rRNA group I, was most closely 
TABLE 1. Phenotypic characteristics of species belonging to the genus Halobacillus

\begin{tabular}{|c|c|c|c|}
\hline Characteristic & $\begin{array}{l}\text { H. halophilus } \\
\text { DSM } 2266^{\mathrm{T} a}\end{array}$ & $\begin{array}{l}\text { H. litoralis } \\
\text { SL-4 }\end{array}$ & $\begin{array}{l}\text { H. trueperi } \\
\text { SL-5 }\end{array}$ \\
\hline Peptidoglycan type & Orn-D-Asp & Orn-D-Asp & Orn-D-Asp \\
\hline Morphology & Coccoid & Rod shaped & Rod shaped \\
\hline Spore production & + & + & + \\
\hline Motility & + & + & + \\
\hline Pigmentation & Orange & Orange & Orange \\
\hline Anaerobic growth & - & - & - \\
\hline $\begin{array}{l}\text { Growth in the presence } \\
\text { of } 0.5 \% \text { salt }\end{array}$ & - & + & + \\
\hline Catalase & + & + & + \\
\hline Oxidase & + & + & + \\
\hline Voges-Proskauer test & - & - & - \\
\hline Nitrate reduction & - & - & - \\
\hline \multicolumn{4}{|l|}{ Acid production from: } \\
\hline D-Fructose & - & + & + \\
\hline D-Galactose & - & - & + \\
\hline Maltose & - & + & + \\
\hline Sucrose & - & + & + \\
\hline D-Xylose & - & + & - \\
\hline D-Glucose & - & + & + \\
\hline D-Mannitol & - & + & - \\
\hline D-Trehalose & - & + & + \\
\hline \multicolumn{4}{|l|}{ Hydrolysis of: } \\
\hline Esculin & - & - & - \\
\hline Casein & + & - & - \\
\hline Gelatin & + & + & + \\
\hline Starch & + & - & - \\
\hline Pullulan & + & - & + \\
\hline Tween 80 & - & - & - \\
\hline Tyrosine & - & - & - \\
\hline \multicolumn{4}{|l|}{ Enzyme activities } \\
\hline DNase & + & + & + \\
\hline Urease & - & - & - \\
\hline Phosphatase & + & - & - \\
\hline Lecithinase & - & - & - \\
\hline $\begin{array}{l}\text { Phenylalanine } \\
\text { deaminase }\end{array}$ & - & - & - \\
\hline Arginine dihydrolase & - & - & - \\
\hline
\end{tabular}

related to strain SL-4 ${ }^{\mathrm{T}}$. The level of similarity between the $16 \mathrm{~S}$ rRNA sequences of these organisms was $94.5 \%$.

The phylogenetic tree in Fig. 2 shows the relationship of strain $\mathrm{SL}-4^{\mathrm{T}}$ to some representative gram-positive bacteria with low DNA $\mathrm{G}+\mathrm{C}$ contents. The inferred tree topology was stable even when we used various sets of alignment positions that differed in their degrees of sequence conservation.

\section{DISCUSSION}

Newly isolated strains SL- $4^{\mathrm{T}}$ and SL- ${ }^{\mathrm{T}}$ are moderately halophilic, aerobic, heterotrophic bacteria that were isolated from a hypersaline sediment characterized by changing levels of salinity that depended on the rainfall or snowmelt. The adaptation of these organisms to this kind of habitat is reflected by their tolerance of a wide range of salt concentrations. In contrast to most other microorganisms isolated from samples obtained from the Great Salt Lake in Utah, which have generation times ranging from 6 to $16.9 \mathrm{~h}(7,18)$, strains SL- ${ }^{\mathrm{T}}$ and SL $-5^{\mathrm{T}}$ grow comparatively fast (generation times, 0.4 to $0.5 \mathrm{~h}$ ).

The data presented in this paper indicate that strains SL- ${ }^{\mathrm{T}}$ and SL $-5^{\mathrm{T}}$ are closely related to Sporosarcina halophila. The following phenotypic characteristics suggest that these organisms should be placed in the same genus: they are Gram pos-
TABLE 2. Overall levels of sequence similarity between strain SL$4^{\mathrm{T}} 16 \mathrm{~S}$ rRNA and $16 \mathrm{~S}$ rRNAs from representative gram-positive bacteria with low DNA $\mathrm{G}+\mathrm{C}$ contents ${ }^{a}$

\begin{tabular}{|c|c|c|c|}
\hline Organism or group & Strain & $\begin{array}{l}\text { Source, } \\
\text { accession } \\
\text { no., or } \\
\text { reference }{ }^{b}\end{array}$ & $\begin{array}{l}\text { \% Similarity } \\
\text { to strain } \\
\text { SL- } 4^{\mathrm{T}}\end{array}$ \\
\hline \multicolumn{4}{|l|}{$\begin{array}{l}\text { Groups containing Bacillus } \\
\text { species and related taxa }\end{array}$} \\
\hline rRNA group I (26 species) & & 1 & $90.8-94.5$ \\
\hline rRNA group II (6 species) & & 1 & $89.3-90.8$ \\
\hline rRNA group III (10 species) & & 1 & $87.0-92.0$ \\
\hline rRNA group IV (2 species) & & 1 & $89.6-90.1$ \\
\hline rRNA group V (3 species) & & 1 & $89.9-91.3$ \\
\hline rRNA group VI ( 9 species) & & 16 & $90.6-92.9$ \\
\hline Sporosarcina halophila & NCIMB 2269 & $\mathrm{X} 62175$ & 97.9 \\
\hline Sporosarcina ureae & NCIMB 9251 & X62174 & 91.0 \\
\hline Planococcus citreus & NCIMB 1493 & $\mathrm{X} 62172$ & 91.6 \\
\hline Planococcus kocurii & NCIMB 629 & X62173 & 91.1 \\
\hline Sporolactobacillus inulinus & ATCC 15538 & M58838 & 89.9 \\
\hline Marinococcus halophilus & NCIMB 2178 & X62171 & 89.7 \\
\hline Staphylococcus camosus & DSM 20501 & X66099 & 89.7 \\
\hline Salinicoccus roseus & DSM 5351 & X94559 & 89.6 \\
\hline Enterococcus faecalis & & RDP & 88.1 \\
\hline Pediococcus acidilactici & DSM 20284 & M58833 & 85.4 \\
\hline Pediococcus pentosaceus & ATCC 33316 & M58834 & 84.7 \\
\hline
\end{tabular}

"In addition to species of the genus Bacillus, most of the strains compared were halophilic or halotolerant bacteria. Ranges of similarity values are given for the six rRNA groups containing Bacillus species and related taxa as defined by Ash et al. (1) and Nielsen et al. (16).

$b$ The accession numbers are the EMBL accession numbers of the sequences analyzed. For each group of organisms, the reference is a reference in which the accession numbers are given. The sequence of Enterococcus faecalis has no accession number and was obtained from the Ribosomal Database Project (RDP) (12).

itive, spore forming, moderately halophilic, and motile and possess peptidoglycan of the Orn-D-Asp type. However, these organisms are phenotypically and chemotaxonomically different from Bacillus halophilus, the only moderately halophilic, obligately aerobic, spore-forming, gram-positive, rod-shaped organism described previously. In fact, $B$. halophilus has peptidoglycan of the meso-diaminopimelic acid type in its cell wall, and its $\mathrm{G}+\mathrm{C}$ content is $51.5 \mathrm{~mol} \%$ (27). A comparative sequence analysis of $16 \mathrm{~S}$ rRNA genes revealed that strain SL-4 ${ }^{\mathrm{T}}$ and Sporosarcina halophila are closely related. The type species of the genus Sporosarcina, Sporosarcina ureae, is not closely

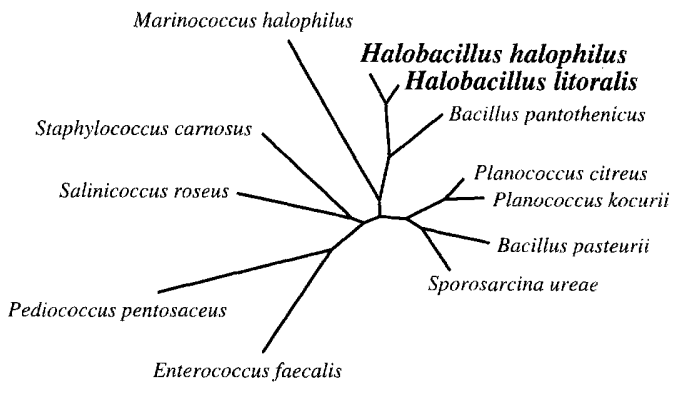

$10 \%$

FIG. 2. Unrooted phylogenetic tree showing the relationship of $H$. litoralis SL-4 ${ }^{\mathrm{T}}$ and $H$. halophila (formerly Sporosarcina halophila) to some other grampositive bacteria. The tree was derived from a distance matrix based on a selection of 16S rRNA sequences of moderately halophilic and nonhalophilic gram-positive bacteria with low DNA G $+\mathrm{C}$ contents. Scale bar $=10 \%$ estimated sequence divergence. 
related to this group of bacteria. The level of similarity between the 16S rRNA sequences of Sporosarcina ureae and Sporosarcina halophila is only $91.0 \%$. Moreover, Sporosarcina ureae is not halophilic and has a peptidoglycan of the Lys-GlyD-Glu type. Therefore, we propose that the new genus Halobacillus should be created for new strains SL- $4^{\mathrm{T}}$ and SL-5 ${ }^{\mathrm{T}}$ and Sporosarcina halophila.

Several phenotypic characteristics allowed us to differentiate Sporosarcina halophila from strains SL $-4^{\mathrm{T}}$ and SL $-5^{\mathrm{T}}$ (Table 1), and the low levels of DNA similarity among the three organisms (maximum level of similarity, $30 \%$ ) justify placing them in three different species. Thus, we propose that SL-4 should be the type strain of Halobacillus litoralis sp. nov. and SL-5 should be the type strain of Halobacillus trueperi sp. nov. Sporosarcina halophila should be transferred to the genus Halobacillus as Halobacillus halophilus.

Description of Halobacillus Spring, Ludwig, Marquez, Ventosa, and Schleifer gen. nov. Halobacillus (Ha.lo.ba.cil'lus. Gr. n. hals, salt; L. n. bacillus, rod; M.L. masc. n. Halobacillus, a salt[-loving] rod). Gram-positive, spore-forming, rod-shaped or spherical to oval cells. Motile by means of flagella. Endospores resist heating at $75^{\circ} \mathrm{C}$ for at least $10 \mathrm{~min}$. The cell wall contains peptidoglycan of the Orn-D-Asp type. Moderately halophilic, strictly aerobic, and chemoorganotrophic. Catalase and oxidase are produced; DNase positive and urease negative. Nitrate is not reduced to nitrite. The Voges-Proskauer reaction is negative. Colonies form an orange nondiffusible pigment. The $\mathrm{G}+\mathrm{C}$ content of the DNA ranges from 40 to $43 \mathrm{~mol} \%$ (as determined by the thermal denaturation method). The type species is Halobacillus halophilus.

Description of Halobacillus litoralis Spring, Ludwig, Marquez, Ventosa, and Schleifer sp. nov. Halobacillus litoralis (li.to.ra'lis. L. adj. litoralis, of the shore). In addition to the characteristics given above in the description of the genus, $H$. litoralis has the following characteristics. Rod-shaped cells are 0.7 to 1.1 by 2.0 to $4.5 \mu \mathrm{m}$ and occur singly, in pairs, or in short chains. Sometimes cells up to $20 \mu \mathrm{m}$ long are present. Motile by means of several flagella, which are inserted at both poles of each cell or laterally. Endospores are ellipsoidal or sometimes spherical and 0.7 to $1.5 \mu \mathrm{m}$ in diameter; they are located at a central to subterminal position. Acid is produced from $\mathrm{D}$-fructose, maltose, sucrose, D-xylose, D-glucose, D-mannitol, and D-trehalose, but not from D-galactose. Gelatin is hydrolyzed, but casein, starch, pullulan, Tween 80 , and tyrosine are not hydrolyzed. Phosphatase is not produced. Growth occurs in media containing 0.5 to $25 \%$ (wt/vol) salt, and the optimum salt concentration is around $10 \%$. The temperature range for growth is 10 to $43^{\circ} \mathrm{C}$, and the optimum temperature is $35^{\circ} \mathrm{C}$. The $\mathrm{pH}$ range for growth is $\mathrm{pH} 6.0$ to 9.5 ; the optimum $\mathrm{pH}$ is 7.5. The doubling time is $0.48 \mathrm{~h}$ under optimal conditions. The $\mathrm{G}+\mathrm{C}$ content of the DNA is $42 \mathrm{~mol} \%$. Isolated from sediment obtained from the southern part of the Great Salt Lake in Utah. The type strain is strain SL-4, which has been deposited in the Deutsche Sammlung von Mikroorganismen und Zellkulturen GmbH, Braunschweig, Germany, as strain DSM 10405.

Description of Halobacillus trueperi Spring, Ludwig, Marquez, Ventosa, and Schleifer sp. nov. Halobacillus trueperi (true'per.i. M.L. gen. n. trueperi, of Trueper, in honor of Hans G. Trüper, who has made important contributions to our knowledge of the ecophysiology and taxonomy of halophilic bacteria). In addition to the characteristics given above in the description of the genus, $H$. trueperi has the following characteristics. Rod-shaped cells are 0.7 to 1.4 by 2.0 to $4.5 \mu \mathrm{m}$ and occur singly, in pairs, or in short chains. Sometimes cells up to $20 \mu \mathrm{m}$ long are present. Motile by means of several flagella, which are inserted at both poles of each cell or laterally. En- dospores are ellipsoidal or sometimes spherical and 0.7 to 1.5 $\mu \mathrm{m}$ in diameter; they are located at a central to subterminal position. Acid is produced from D-fructose, D-galactose, maltose, sucrose, D-glucose, and D-trehalose, but not from D-xylose and D-mannitol. Gelatin and pullulan are hydrolyzed, but casein, starch, Tween 80, and tyrosine are not hydrolyzed. Phosphatase is not produced. Growth occurs in media containing 0.5 to $30 \%$ (wt/vol) salt, and the optimum salt concentration is around $10 \%$. The temperature range for growth is 10 to $44^{\circ} \mathrm{C}$, and the optimum temperature is $35^{\circ} \mathrm{C}$. The $\mathrm{pH}$ range for growth is $\mathrm{pH} 6.0$ to 9.5 ; the optimum $\mathrm{pH}$ is 7.5 . The doubling time is $0.42 \mathrm{~h}$ under optimal conditions. The $\mathrm{G}+\mathrm{C}$ content of the DNA is $43 \mathrm{~mol} \%$. Isolated from sediment obtained from the southern part of the Great Salt Lake in Utah. The type strain is strain SL-5, which has been deposited in the Deutsche Sammlung von Mikroorganismen und Zellkulturen $\mathrm{GmbH}$, Braunschweig, Germany, as strain DSM 10404.

Transfer of Sporosarcina halophila to the genus Halobacillus as Halobacillus halophilus comb. nov. Halobacillus halophilus (ha.lo'phi.lus. Gr. n. hals, salt; Gr. adj. philus, loving; M.L. masc. adj. halophilus, salt loving). Physiological, chemotaxonomic, and phylogenetic data indicate that Sporosarcina halophila is more closely related to $H$. litoralis and $H$. trueperi than to Sporosarcina ureae, the type species of the genus Sporosarcina. The original description of the species given by Claus et al. (2) is unchanged.

\section{ACKNOWLEDGMENTS}

We thank N. Weiss for confirming the results of our cell wall analysis, W. Liebl for testing the ability of the strains which we studied to decompose polymers, and R. Rossello-Mora for help with the DNADNA hybridization experiments.

\section{REFERENCES}

1. Ash, C., J. A. E. Farrow, S. Wallbanks, and M. D. Collins. 1991. Phylogenetic heterogeneity of the genus Bacillus revealed by comparative analysis of small-subunit ribosomal RNA sequences. Lett. Appl. Microbiol. 13:202-206.

2. Claus, D., F. Fahmy, H. J. Rolf, and N. Tosunoglu. 1983. Sporosarcina halophila sp. nov, an obligate, slightly halophilic bacterium from salt marsh soils. Syst. Appl. Microbiol. 4:496-506.

3. Claus, D., D. Fritze, and M. Kocur. 1992. Genera related to the genus Bacillus, p. 1769-1791. In A. Balows, H. G. Trüper, M. Dworkin, W. Harder, and K. H. Schleifer (ed.), The prokaryotes, 2nd ed., vol. 2. Springer-Verlag, New York.

4. De Ley, J. 1970. Reexamination of the association between melting point, buoyant density, and chemical base composition of deoxyribonucleic acid. J. Bacteriol. 101:738-754.

5. Drews, G. 1983. Mikrobiologisches Praktikum, 4th ed. Springer-Verlag, Berlin.

6. Fahmy, F., F. Mayer, and D. Claus. 1985. Endospores of Sporosarcina halophila: characteristics and ultrastructure. Arch. Microbiol. 140:338-342.

7. Fendrich, C. 1988. Halovibrio variabilis gen. nov. sp. nov., Pseudomonas halophila sp. nov. and a new halophilic aerobic coccoid eubacterium from Great Salt Lake, Utah, USA. Syst. Appl. Microbiol. 11:36-43.

8. Fendrich, C., H. Hippe, and G. Gottschalk. 1990. Clostridium halophilum sp. nov. and $C$. litorale sp. nov., an obligate halophilic and a marine species degrading betaine in the Stickland reaction. Arch. Microbiol. 154:127-132.

9. Heimbrook, M. E., W. L. L. Wang, and G. Campbell. 1989. Staining bacterial flagella easily. J. Clin. Microbiol. 27:2612-2615.

10. Kushner, D. J., and M. Kamekura. 1988. Physiology of halophilic eubacteria, p. 109-138. In F. Rodriguez-Valera (ed.), Halophilic bacteria, vol. 1. CRC Press, Inc., Boca Raton, Fla.

11. Lind, E., and J. Ursing. 1986. Clinical strains of Enterobacter agglomerans (synonyms: Erwinia herbicola, Erwinia milletiae) identified by DNA-DNA hybridization. Acta Pathol. Microbiol. Immunol. Scand. Sect. B 94:205-213.

12. Maidak, B. L., N. Larsen, M. J. McCaughey, R. Overbeck, G. Olsen, K. Fogel, J. Blandy, and C. R. Woese. 1994. The Ribosomal Database Project. Nucleic Acids Res. 22:3485-3487.

13. Mandel, M., and J. Marmur. 1968. Use of ultraviolet absorbance temperature profile for determining the guanine plus cytosine content of DNA. Methods Enzymol. 12B:195-206.

14. Marmur, J., and P. Doty. 1961. Thermal renaturation of deoxyribonucleic acids. J. Mol. Biol. 3:585-594.

15. Meyer, S. A., and K. H. Schleifer. 1975. Rapid procedure for the approxi- 
mate determination of the deoxyribonucleic acid base composition of micrococci, staphylococci, and other bacteria. Int. J. Syst. Bacteriol. 24:383385 .

16. Nielsen, P., F. A. Rainey, H. Outtrup, F. G. Priest, and D. Fritze. 1994. Comparative $16 \mathrm{~S}$ rDNA sequence analysis of some alkaliphilic bacilli and the establishment of a sixth rRNA group within the genus Bacillus. FEMS Microbiol. Lett. 117:61-66.

17. Onishi, H., and M. Kamekura. 1972. Micrococcus halobius sp. nov. Int. J. Syst. Bacteriol. 22:233-236.

18. Post, F. J. 1977. The microbial ecology of the Great Salt Lake. Microb. Ecol. 3:143-165.

19. Quesada, E., A. Ventosa, F. Ruiz-Berraquero, and A. Ramos-Cormenzana. 1984. Deleya halophila, a new species of moderately halophilic bacteria. Int. J. Syst. Bacteriol. 34:287-292.

20. Rossello-Mora, R., F. Caccavo, Jr., K. Osterlehner, N. Springer, S. Spring, D. Schüler, W. Ludwig, R. Amann, M. Vanncanneyt, and K. H. Schleifer. 1994. Isolation and taxonomic characterization of a halotolerant, facultatively iron-reducing bacterium. Syst. Appl. Microbiol. 17:569-573.

21. Saitou, N., and M. Nei. 1987 . The neighbor-joining method: a new method for reconstructing phylogenetic trees. Mol. Biol. Evol. 4:406-425.

22. Schleifer, K. H., and O. Kandler. 1972. Peptidoglycan types of bacterial cell walls and their taxonomic implications. Bacteriol. Rev. 36:407-477.

23. Spring, S., R. Amann, W. Ludwig, K. H. Schleifer, D. Schüler, K. Poralla, and N. Petersen. 1994. Phylogenetic analysis of uncultured magnetotactic bacteria from the alpha-subclass of Proteobacteria. Syst. Appl. Microbiol. 17:501-508.

24. Springer, N., W. Ludwig, R. Amann, H. J. Schmidt, H. D. Görtz, and K. H. Schleifer. 1993. Occurrence of fragmented 16S rRNA in an obligate bacterial endosymbiont of Paramecium caudatum. Proc. Natl. Acad. Sci. USA 90: 9892-9895.

25. Van de Peer, Y., I. Van den Broeck, P. De Rijk, and R. De Wachter. 1994. Database on the structure of small ribosomal subunit RNA. Nucleic Acids Res. 22:3488-3494.

26. Ventosa, A. 1994. Taxonomy and phylogeny of moderately halophilic bacteria, p. 231-242. In F. G. Priest, A. Ramos-Cormenzana, and B. J. Tindall (ed.), Bacterial diversity and systematics. Plenum Press, New York.

27. Ventosa, A., M. T. Garcia, M. Kamekura, H. Onishi, and F. Ruiz-Berraquero. 1989. Bacillus halophilus sp. nov., a moderately halophilic Bacillus species. Syst. Appl. Microbiol. 12:162-166.

28. Ventosa, A., M. C. Marquez, N. Weiss, and B. J. Tindall. 1992. Transfer of Marinococcus hispanicus to the genus Salinicoccus as Salinicoccus hispanicus comb. nov. Syst. Appl. Microbiol. 15:530-534.

29. Ventosa, A., E. Quesada, F. Rodriguez-Valera, F. Ruiz-Beraquero, and A. Ramos-Cormenzana. 1982. Numerical taxonomy of moderately halophilic Gram-negative rods. J. Gen. Microbiol. 128:1959-1968. 